\title{
EVALUATION OF PLASMA LEVEL OF HOMOCYSTEINE IN THE PERIPHERAL AND PENILE BLOOD BEFORE AND AFTER FOLIC ACID SUPPLENTATION IN VASCULOGENIC ERECTILE DYSFUNCTION PATIENTS
}

\author{
By
}

\author{
Ibraheim Mohammed Shahein ${ }^{1}$, Yaser Fathy Mohammed ${ }^{1}$, Ahmed \\ Rashaad Mohammed ${ }^{1}$, Wafik Ibrahim Ali $^{2}$,Nabil Fathy Ismail ${ }^{3}$, Hazem \\ Basuony El-Razek ${ }^{4 *}$ \\ ${ }^{1}$ Dermatology, Venereology and Andrology, Faculty of Medicine, Al-Azhar University, \\ ${ }^{2}$ Clinical Radiology, Faculty of Medicine, Al-Azhar University, \\ ${ }^{3}$ Clinical Pathology, Faculty of Medicine, Al-Azhar University, \\ ${ }^{4}$ Dermatology, Venereology and Andrology at Etay Elbaroud Hospita, Elbehira, Egypt \\ E-mail: hazem.bassiony.1988@gmail.com
}

\begin{abstract}
Background: Erectile function may be secondary to much systemic illness, both physical and psychological, and is a well-documented side effect of prostatic cancer treatment.

Objective: To asses effect of folic acid supplementation on homocysteine plasma level in either peripheral and penile blood before among vasculogenic erectile dysfunction patients.

Patients and methods: This study included 22 Egyptian patients ranged from 30-60 years old with vasculogenic ED proved by penile duplex ultrasound. All patients subjected to penile Duplex ultrasound, peripheral and penile blood samples were for plasma homocysteine concentration evaluation before and after oral folic acid $500 \mathrm{mcg}$ per day for 3 months.

Results: There was statistically significant difference between either peripheral or penile homocystiene before and after. There was a significant increase in peak systolic value (PSV) after the treatment than its value before the treatment. Also, the end-diastolic velocity (EDV) before therapy was significantly higher than its value after therapy. There was a significant increase in international index of erectile Function-5 questionnaire after the treatment (15.5 \pm 3.3$)$ than its value before the treatment.

Conclusion: There was a significant relation between Hcys and either ED or penile arterial flow. From these results, Elevated plasma Hcys level was considered as independent risk factor for ED.
\end{abstract}

Key words: Erectile dysfunction, Folic acid, Homocysteine, Penile, Plasma, Vasculogenic.

\section{INTRODUCTION}

Erectile dysfunction (ED) was defined as the persistent inability to either obtain or maintain erected penis sufficient for a satisfactory sexual performance. The vascular component was commonly identified as the cause of ED than psychogenic factors. The prevalence of ED increase with higher age and highest 
incidence was reported among men aged 30 to 80 as affecting up to $53.4 \%$ of years.

In addition to traditional risk factors as age, body weight and smoking, atherosclerosis of blood vessels one of the pathophysiological mechanism can associate with vasculogenic ED development (Rajendran et al., 2013).

Experimental models have explored the pathologic role of hyperhomocysteinemia (HHcys) in development of ED as it strong and independent predictor for atherosclerosis progression and interfere with cavernosal perfusion and these findings confirmed by study assessed Hcys as a relevant risk factor for ED (Giovannone et al., 2015).

The aim of this work was to evaluate the plasma level of homocysteine in the peripheral and penile blood before and after folic acid supplementation in vasculogenic erectile dysfunction patients.

\section{PATIENTS AND METHODS}

This study included 22 Egyptian patients ranged from 30-60 years old with vasculogenic ED proved by penile duplex ultrasound recruited at Al-Azhar University Hospitals outpatient clinics from April 2017 to April 2019 after obtaining informed signed consents and approved from local ethical committee of the hospital. All patients were with stable marital status.

Exclusion criteria included advanced age $(\geq 60$ years), psychogenic and neurogenic erectile dysfunction, penile abnormalities, penile prosthesis, diabetes, pelvic trauma, history of coronary arterial diseases, metabolic diseases, hypogonadism and other hormonal disorders, thyroid diseases, neurological diseases as Parkinsonism, stroke, vitamin b12 or folic acid intake three months before the study and alcoholism.

All patients were subjected to collection of general information and history taking including (age, weight, height, marital status, smoking and drinking status, history of drug intake, and history of any associated other diseases, level of education and duration of the ED, complete physical and anthological examination, international index of erectile function-5 questionnaire (IIEF-5 questionnaire $\geq 21$ ) and penile duplex ultrasound.

All patients underwent baseline and dynamic penile Doppler ultrasonography using a $7.5-13 \mathrm{MHz}$ high frequency ultrasound probe. Patients were examined and the cavernous arteries were studied at baseline conditions after tactile stimulation and then following intracorporal injection of 5 to $20 \mathrm{mg}$ of alprostadil. Vascular flow parameters were registered at baseline and again at 5, 10, and 20 minutes postinjection. Patients were assessed with the penis aimed onto the abdomen and the probe was placed on the ventral penile surface. Dopplex examinations were performed by a single operator to minimize possible variability and normal response was defined by a peak-systolic velocity (PSV) more than 30 $\mathrm{cm} / \mathrm{second}$, end-diastolic velocity (EDV) under $3 \mathrm{~cm} / \mathrm{second}$ and resistive index [RI $1 / 4(\mathrm{PSV}$ EDV)/PSV] more than 0.8. Diagnosis criteria for ED included arterial insufficiency (PSV > $30 \mathrm{~cm} / \mathrm{second}$, EDV $>5 \mathrm{~cm} /$ second), veno-occlusive dysfunction (EDV > $5 \mathrm{~cm} /$ second, PSV < $30 \mathrm{~cm} /$ second, RI $<0.8$ ), and mixed 
vascular disorder $(\mathrm{PSV}<30 \mathrm{~cm} / \mathrm{second}$, EDV $>5 \mathrm{~cm} /$ second, $\mathrm{RI}<0.8)$.

In the morning after overnight fasting, blood samples were collected to assess plasma homocysteine concentration in either peripheral and penile blood samples, fasting and post prandial blood glucose, thyroid stimulating hormone (TSH), free T3 and T4, follicular stimulating hormone (FSH), luteinizing hormone $(\mathrm{LH})$, prolactin, free testosterone and lipid profile (total cholesterol, low density lipoprotein (LDL), high density lipoprotein (HDL) and triglycerides).

Patient satisfaction was assessed by a 4 point scale: (0) unsatisfied, (1) mildly satisfied, (2) moderately satisfied and well satisfied.
Correlation between peripheral and penile homocystein with penile duplex Iindies were done. All patients were receiving oral folic acid $500 \mathrm{mcg}$ per day for 3 months, and then fellow up was done 3 months.

\section{Statistical analysis:}

Data were analyzed using Statistical Program for Social Science (SPSS) version 15.0. Quantitative data were presented as mean \pm standard deviation (SD) while Qualitative data were presented as frequency, percentage and correlation. Two means were compared using paired t-test of significance, while Chi-square test was used to compare between non-parametric data. P-value < 0.05 was considered significant.

\section{RESULTS}

Peripheral homocysteine significantly decreased after therapy than before treatment $(1.05 \pm 3.4$ versus $28.6 \pm 47.5$, $\mathrm{p}=0.01)$. Also, penile homocystein showed significant decrease after treatment $(0.3 \pm 0.8$ versus1.7 \pm 2.6 before treatment, $\mathrm{p}=0.02$ )
Table (1) showed a statistically significant difference between either peripheral or penile homocystiene before and after therapy ( $\mathrm{p}$-value $=0.01 \& 0.03$ respectively).

Table (1): Comparison between peripheral and penile homocystiene before and after therapy

\begin{tabular}{|l|c|c|c|c|}
\hline \multicolumn{2}{|c|}{ Groups } & $\begin{array}{c}\text { Before } \\
(\mathbf{N = 2 2})\end{array}$ & $\begin{array}{c}\text { After } \\
(\mathbf{N}=\mathbf{2 2})\end{array}$ & \multirow{2}{*}{ p-value } \\
\hline $\begin{array}{l}\text { Variables } \\
\text { Peripheral } \\
\text { homocystiene }\end{array}$ & Mean & 28.6 & 1.05 & \multirow{2}{*}{$\mathbf{0 . 0 1}$} \\
\cline { 2 - 4 } $\begin{array}{l}\text { penile } \\
\text { homocystiene }\end{array}$ & Mean & 47.5 & 3.4 & 0.7 \\
\cline { 2 - 4 } & $\mathbf{\pm S D}$ & 2.6 & 0.3 & $\mathbf{0 . 0 2}$ \\
\hline
\end{tabular}

This study showed that, there was significant increase in peak systolic value (PSV) after the treatment (28.5 \pm 5.6$)$ than its value before the treatment $(23.1 \pm 4.9)$ as $\mathrm{p}=0.002$. Also, the end-diastolic velocity (EDV) before therapy $(12.2 \pm 1.9)$ was significantly higher than its value after therapy $(9.2 \pm 1.4)(\mathrm{p}<0.001)$.

Before the therapy, the majority of cases was mixed type (68.2\%)while after 
the therapy, there was improvement in arterial component and the majority become venogenic type $(59.1 \%)$ with no statistically significant difference between ED type before and after therapy $(\mathrm{p}=0.09)$. Also, there was significant increase in International Index of Erectile Function-5 questionnaire after the treatment $(15.5 \pm 3.3)$ than its value before the treatment $(6.4 \pm 1.05)$ as $\mathrm{p}<0.001$.

This study showed that, before therapy non-significant negative correlation between peripheral homocystiene and penile homocystiene ( $\mathrm{r}=-0.06 \& \mathrm{p}=0.8) \&$ $\operatorname{EDV}(\mathrm{r}=-0.4 \& \mathrm{p}=0.05)$ and nonstatistical significant positive correlation between peripheral homocystiene and PSV $(r=0.2 \& p=0.3) \& \operatorname{IIEF}(r=0.1 \& p=$ $0.6)$. On the other hands after therapy, there was highly statistical significant Positive correlation between peripheral homocystiene and penile homocystiene $(r=0.9 \& p<0.001)$, while Non-significant negative correlation between peripheral homocystiene and PSV $(\mathrm{r}=-0.2 \& \mathrm{p}=0.4)$, $\operatorname{EDV}(\mathrm{r}=-0.1 \& \mathrm{p}=0.6) \& \operatorname{IIEF}(\mathrm{r}=-0.1 \&$ $\mathrm{p}=0.4)$.

The description of patient satisfaction among studied patients. 1 patient $(4.5 \%)$ was unsatisfied, 8 patients $(36.4 \%)$ were well satisfied and 13 patients $(59.1 \%)$ were moderately satisfied. Regarding IIFE 5 grading before therapy in studied patients. 17 patients $(77.3 \%)$ were moderate while the remaining 5 patients $(22.7 \%)$ were severe. While after therapy in studied patients. All patients (100\%) were mild. with highly statistically significant difference ( $\mathrm{p}$-value $<0.001$ ) between IIEF 5 grading before $(6.4 \pm 1.05)$ and after therapy $(15.5 \pm 3.3)$ as $\mathrm{p}$ value $<0.001$. And there was no statistical significant difference between peripheral and penile homocystiene as regard IIEF grading before therapy ( $\mathrm{p}$-value $=0.8$ for both) (Table 2).

Table (2): Comparison peripheral and penile homocystiene as regard IIEF grading before therapy

\begin{tabular}{|c|c|c|c|c|}
\hline \multicolumn{2}{|c|}{$\begin{array}{ll}\text { Bariables } & \text { Before therapy } \\
\end{array}$} & \multirow{2}{*}{$\begin{array}{c}\text { Moderate } \\
17 \\
77.3 \% \\
\end{array}$} & \multirow{2}{*}{$\begin{array}{c}\text { Severe } \\
5 \\
22.7 \% \\
\end{array}$} & \multirow{2}{*}{$\begin{array}{c}\text { p-value } \\
<0.001\end{array}$} \\
\hline IIEF 5 & $\begin{array}{l}\mathbf{N} \\
\%\end{array}$ & & & \\
\hline \multirow{2}{*}{$\begin{array}{l}\text { Peripheral } \\
\text { homocystiene }\end{array}$} & Mean & 29.9 & 24.2 & \multirow{2}{*}{0.8} \\
\hline & $\pm \mathrm{SD}$ & 50.1 & 42.2 & \\
\hline \multirow{2}{*}{$\begin{array}{l}\text { Penile } \\
\text { homocystiene }\end{array}$} & Mean & 1.8 & 1.4 & \multirow{2}{*}{0.8} \\
\hline & $\pm \mathrm{SD}$ & 2.7 & 2.4 & \\
\hline
\end{tabular}

Regarding the description of peripheral and penile homocystiene as regard IIEF grading after therapy. As regard peripheral homocyctiene, the mean was $1.05 \pm 3.39$ with minimum value of 0 and maximum

\section{DISCUSSION}

Hyperhomocysteinemia (HHcys) associated with decreased expression and activation of endothelial nitric oxide (NOS) and inhibits nitric oxide synthase value of 16. As regard penile homocyctiene, the mean was $0.3 \pm 0.83$ with minimum value of 0 and maximum value of 4 .

activity in endothelial cells through threonine 495 phosphorylation and protein kinase $\mathrm{C}$ pathways. So, Hcys remains a putative risk factor for ED (Zhang et al., 2017). The accumulation of Hcys has deleterious effects on cells, including 
induction of vascular diseases such as atherosclerosis. There are six main mechanisms explained the role of HHcy in development of EDys: inhibition of nitric oxide (NO), regulation of prostanoid, suppression of endothelium-derived hyperpolarizing factor, activation of angiotensin II receptor-1, induction of endothelin-1 and activation of oxidative stress (Yan et al., 2014).

This study showed that, the peripheral homocystiene \& penile homocystiene before therapy was significantly higher than its value after therapy With significantly difference between peripheral and penile Homocystiene before the treatment, while no significant difference between both values after treatment. Also, there was no statistical significant difference in peripheral and penile homocystiene between moderate and sever grade before therapy.

This study showed that there was a significant increase in peak systolic value (PSV) after the treatment than its value before the treatment. Also, the enddiastolic velocity (EDV) before therapy was significantly higher than its value after therapy.

This study showed that there was a significant increase in IIEF 5 after the treatment than its value before the treatment.

This study showed, before therapy, non-significant negative correlation between peripheral homocystiene and penile homocystiene and non-statistical significant positive correlation between peripheral homocystiene and PSV. On the other hands after therapy, there was highly statistical significant Positive correlation between peripheral homocystiene and penile homocystiene, while Nonsignificant negative correlation between peripheral homocystiene and PSV, EDV. These results indicate the impairment of the penile arterial dispensability and secondary hyperhomocysteinemia and was responsible for impaired production of endothelium-dependent vasorelaxant substances and this reduced penile arterial flows.

This study showed that, regarding the description of patient satisfaction; $4.5 \%$ was unsatisfied, $36.4 \%$ were well satisfied and $59.1 \%$ were moderately satisfied. Although the rates for patient and their partner satisfaction varied widely between the studies but the majority of studies reported high rates of satisfaction by $80 \%$ for excellent response in response to therapy (Burnett et al., 2018).

This study showed that there was a highly statistically significant difference between IIEF 5 grading before and after therapy $(p<0.001)$ as before therapy; 17 patients $(77.3 \%)$ were moderate while the remaining 5 patients $(22.7 \%)$ were severe. After therapy, all patients $(100 \%)$ were mild IIFE 5. The lack of measure folic acid level was one of the limitations of this study. In addition, exclusion of different risk factors as DM, HTN, and other systemic comorbidities which significantly affected the Hcys level. Furthermore, the small sample size of this study and the single-center nature also had significant impact on results validation in addition to the single measurement of the Hcys. We not performed genetic testing to assess the prevalence of MTHFR mutations or checked for folic acid intake with regular meal. 
Series of comprehensive blinded studies were necessary to confirm the usefulness of this biomarker; also, more studies were required to demonstrate the effect of folic acid supplementation on erectile function in ED patients with different systemic illness as diabetes mellitus or hypertension.

\section{CONCLUSION}

Hcys was significantly associated with ED and penile arterial flow as assessed by penile Duplex ultrasound.

Our interventional study was one of the first to demonstrate the lowering effect of folic acid supplementation on Hcys level in patients with idiopathic vasculogenic ED. Thus, folic acid was potentially safe drug should be prescribed concomitantly with phosphodiesterase type 5 inhibitors in ED patients to potentiated their effects. According to these findings, Hcys could be a novel biomarker in the detection of ED and therapy targeted to correct its level may represent a future target for therapy.

\section{CONFLICT OF INTEREST}

Nothing.

\section{REFERENCES}

1. Basar MM, Ozkan Y, Kisa U and Simsek B. (2013): Serum homocysteine levels and sildenafil $50 \mathrm{mg}$ response in young-adult male patients without vascular risk factors. Indian Journal of Biochemestry and Biophysics, 50(3): 215-20.

2. Burnett AL, Nehra A, Breau RH, Culkin DJ, Faraday MM, Hakim LS and Nelson CJ. (2018): Erectile dysfunction: AUA guideline. The Journal of Urology, 200(3):633-41.

3. Enquobahrie DA, Feldman HA, Hoelscher DH, Steffen LM, Webber LS, Zive MM and Osganian SK. (2012): Serum homocysteine and folate concentrations among a US cohort of adolescents before and after folic acid fortification. Public Health Nutrition, 15(10):1818-26.

4. Giovannone R, Busetto GM, Antonini G, De Cobelli O, Ferro M, Tricarico $S$ and Gentile V. (2015): Hyperhomocysteinemia as an early predictor of erectile dysfunction: International Index of Erectile Function (IIEF) and penile Duplex ultrasound correlation with plasma levels of homocysteine. Medicine, 94(39): 1-6.

5. Lombardo F, Tsamatropoulos P, Piroli E, Culasso F, Jannini EA, Dondero $F$ and Gandini L. (2010): Treatment of erectile dysfunction due to C677T mutation of the MTHFR gene with vitamin B6 and folic acid in patients non responders to PDE5i. The journal of sexual Medicine, 7(1):216-23.

6. Rajendran $\mathbf{P}$, Rengarajan $\mathrm{T}$, Thangavel $\mathrm{J}$, Nishigaki Y, Sakthisekaran D, Sethi G and Nishigaki I. (2013): The vascular endothelium and human diseases. International Journal of Biological Sciences, 9(10):1057-69.

7. Safarinejad MR, Safarinejad $S$ and Shafiei N. (2010): Role of methylenetetrahydrofolate reductase gene polymorphisms (C677T, A1298C, and G1793A) in the development of early onset vasculogenic erectile dysfunction. Archives of Medical Research, 41(6):410-22.

8. Yan W-J, Yu N, Yin T-L, Zou Y-J and Yang J. (2014): A new potential risk factor in patients with erectile dysfunction and premature ejaculation: folate deficiency. Asian Journal Of Andrology, 16(6):902-6.

9. Zhang Z, Xu Z, Dai Y and Chen Y. (2017): Elevated serum homocysteine level as an independent risk factor for erectile dysfunction: a prospective pilot case-control study. Andrologia, 49(6):e12684-91.

10. Zhang Z, Zhu L-L, Jiang H-S, Chen H, Chen $Y$ and Dai Y-T. (2016): Demethylation treatment restores erectile function in a rat model of hyperhomocysteinemia. Asian Journal Of Andrology, 18(5):763-8. 
تقييم مستوى الهوموسيستين في بلازما الدم الطرفي

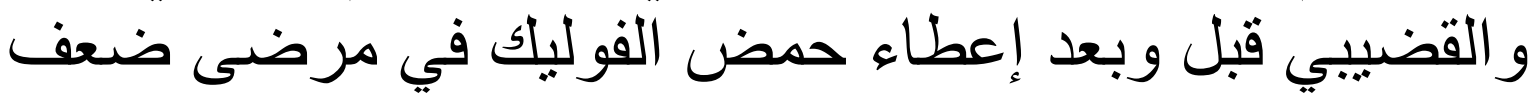

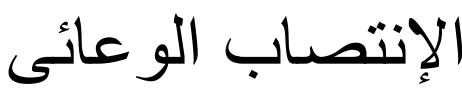

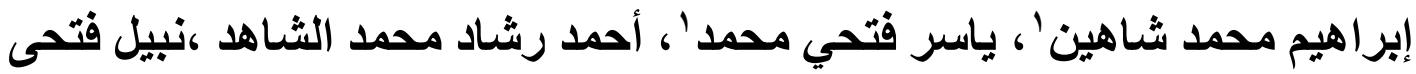

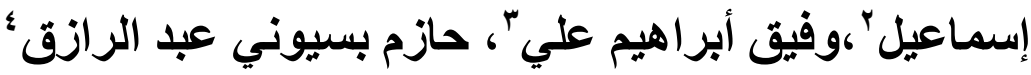

'الأمراض الجلاية والتتاسلية والذكورة، كلية الطب، جامعة الأزهر،

'الأثقعة السريرية، كلية الطب، جامعة الأزهر،

" علم الأمر اض السريري، كلية الطب، جامعة الأزهر،

4الأمراض الجلدية والتناسلية والذكورة، مستثفى ايتاي البارود، البحيرة، جمهورية مصر العربية

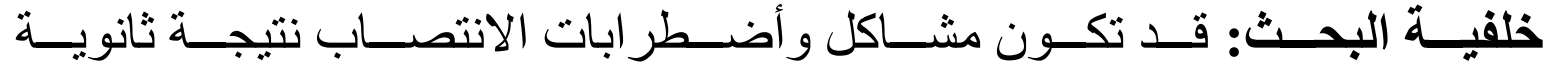

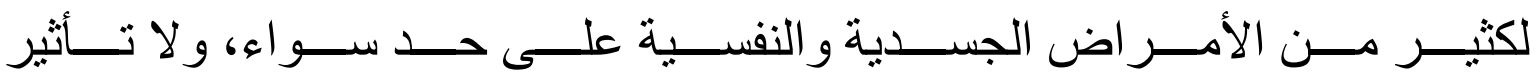
جانبي موثق جيدًا لعلاج سرطان البروستاتا.

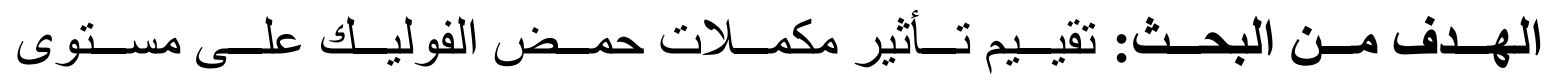

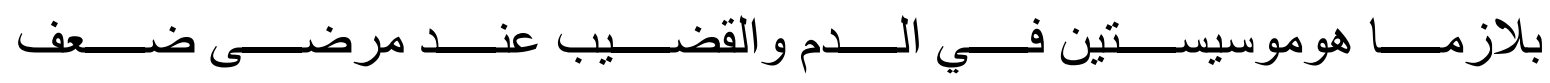

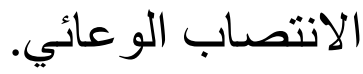

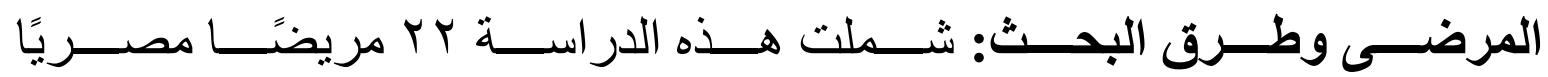

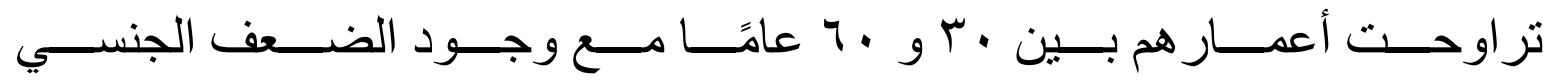

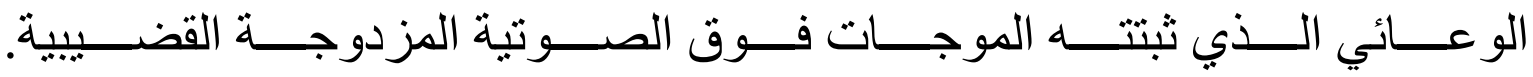

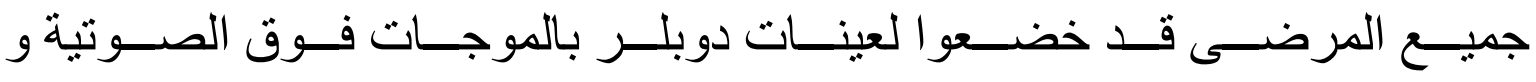

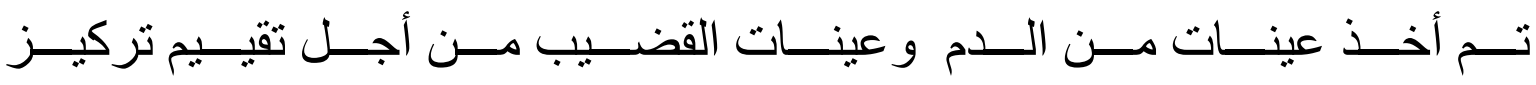

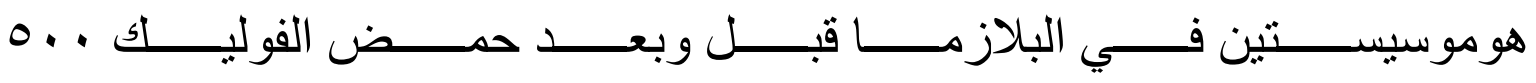
ميكروغر ام يوميًا عن طريق الفم لمدة ب أنثهر. 


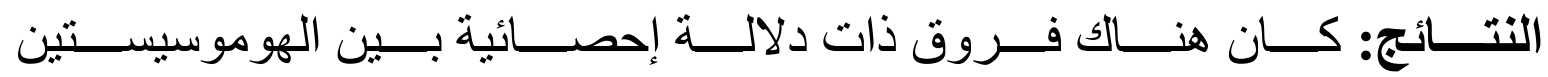

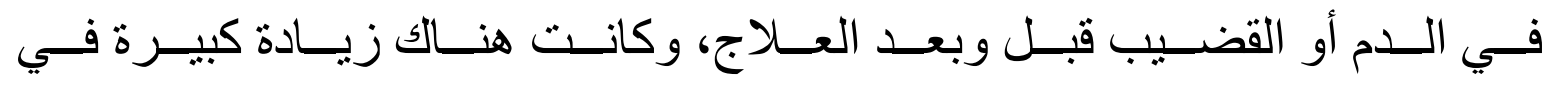

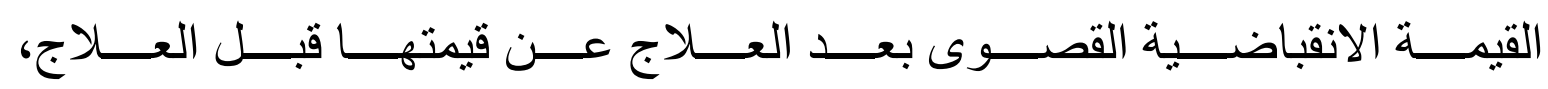

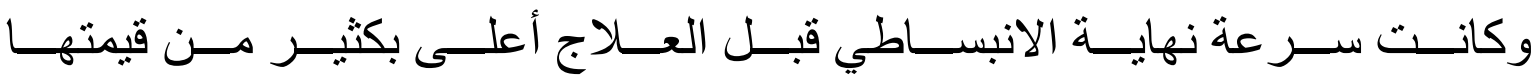

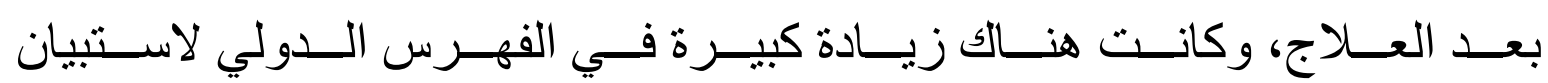
دالة الانتصاب بعد العلاج عن قيمته قبل العلاج.

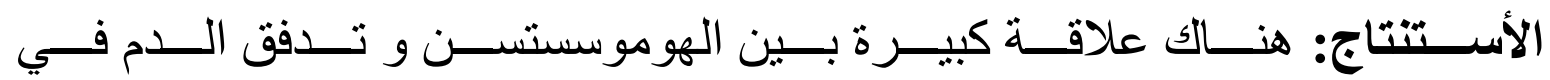

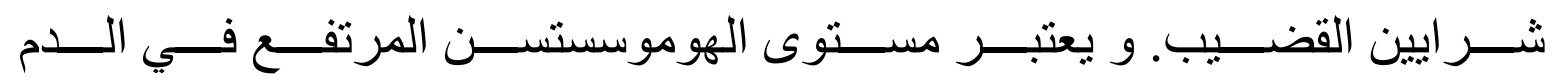
عامل خطر للأصابة بل لضعف الجنسي. 